\title{
Intelligence assessment of deaf students with TONI 3
}

\author{
Anna Carolina Cassiano Barbosa - Universidade Presbiteriana Mackenzie, São Paulo, Brasil \\ Katerina Lukasova - Universidade Cruzeiro do Sul, São Paulo, Brasil \\ Tatiana Pontrelli Mecca - Universidade Presbiteriana Mackenqie, São Paulo, Brasil \\ Elizen Coutinho Macedo - Universidade Presbiteriana Mackenzie, São Paulo, Brasil
}

\begin{abstract}
The intelligence assessment of deaf and hard-of-hearing students has been a challenge for Brazilian psychologists, due to the lack of standardized and validated instruments for this population. The objective of this study was to assess the intelligence of deaf and hard-of-hearing students with the Test of Nonverbal Intelligence, Third Edition (TONI-3: Forma A) according to external variables: age, education, gender, type of deafness, use of hearing aid and communication mode. Study participants were 205 deaf students of both genders, with an average age of 14 years, from four public schools, ranging from elementary to middle school. Results showed no significant differences between subjects according to gender, type of deafness and communication mode. There was an increase in test scores with increasing age, grade and differences between students that used hearing aids. Thus, the findings demonstrate the validity of the TONI-3 to assess the intelligence of Brazilian deaf students.
\end{abstract}

Keywords: Deaf, Intelligence, TONI-3

Avaliação de inteligência de estudantes surdos com o TONI 3

\section{Resumo}

A avaliação de inteligência em estudantes surdos tem sido um desafio para psicólogos brasileiros, devido à falta de instrumentos validados e padronizados para esta população. O objetivo deste estudo foi avaliar a inteligência de estudantes surdos com o Teste de Inteligência Não Verbal, Terceira Edição (TONI-3: Forma A) a partir das variáveis idade, escolaridade, tipo de surdez, uso de aparelho auditivo e modo de comunicação. Participaram 205 estudantes de ambos os sexos, com idade média de 14 anos, de quatro escolas públicas de Ensino Fundamental a Ensino Médio. Os resultados mostraram que não houve diferenças significativas de acordo com gênero, tipo de deficiência auditiva e modo de comunicação. Foram observados aumento nos escores em função do aumento da idade, escolaridade e diferenças entre estudantes que usam aparelho auditivo. Os achados demonstram evidências de validade do TONI-3 para avaliação de inteligência de estudantes surdos no Brasil.

Palavras-chave: Surdos, Inteligência, TONI-3.

\section{Evaluación de la inteligencia de los alumnos sordos con TONI 3}

\begin{abstract}
Resumen
La evaluación de la inteligencia de estudiantes sordos y con sordez profunda ha sido un reto para los psicólogos brasileños, debido a la falta de instrumentos validados y estandarizados para esta población. El objetivo de este estudio fue evaluar la inteligencia de los alumnos sordos y con sordez profunda a través del Test de Inteligencia No Verbal, tercera edición (TONI-3: Forma A) de acuerdo a las variables externas: edad, educación, sexo, tipo de sordera, el uso de audífonos y modo de comunicación. Participaron 205 estudiantes sordos de ambos los sexos, con una edad media de 14 años, de cuatro escuelas públicas desde la primaria a la secundaria. Los resultados no mostraron diferencias significativas en función del sexo, el tipo de pérdida auditiva y modo de comunicación. Se observó un aumento en las puntuaciones en función de la edad, la escolaridad y las diferencias entre los estudiantes que usaban audífonos. Los hallazgos demostraron validez para el TONI-3 para la evaluación de la inteligencia de estudiantes sordos brasileños.

Palabras clave: Sordos, Inteligencia, TONI-3.
\end{abstract}

Intelligence is a composite construct involving various variables including: age, educational level, social level, environmental stimulation, educational level of parents and genetics (Nisbett at al., 2012). Thus, such variables are considered in studies that search for evidence of validity in intelligence tests. These studies have focused mainly on normal subjects. However, it can be inferred from the studies that such variables should also be considered for intelligence assessment in the deaf population (Kushalnagar at al., 2007; Krouse \& Braden, 2011).

The importance of intelligence assessment can be attributed to the fact that the literature suggests relationships between communication, adaptive behavior, functional outcome and cognition in deaf people. An assessment of these features is necessary for a better understanding of this group (Mayberry, 2002; Kushalnagar at al., 2007). Huber and Kipman (2012) assessed children with cochlear implants and normal-hearing peers matched for age and sex. Cognitive skills, including intelligence, and academic achievement were also evaluated. The results showed that deaf children achieved lower scores in crystallized intelligence tests, such as Vocabulary and Comprehension subtests of Wechsler Intelligence Scale (WISC-III). It was also observed that the cognitive 
skills correlated significantly with academic achievement, indicating that in normal-hearing, as well as in children with cochlear implants, the cognitive performance is related to successful learning and acquisition of academic skills.

No between-group differences were found, however, in the evaluation of nonverbal performance by Coding subtest (WISC III) and Corsi Block Tapping Task. Both tests assess visual-spatial abilities of working memory and selective visual attention (Huber \& Kipman, 2012). The results suggest that nonverbal tests of intelligence may be more adequate than verbal ones for deaf people.

According to Wood and Dockrell (2010) cognitive differences between deaf, hard of hearing and hearing children are important distinctions to be taken into account when planning intervention strategies. Edward and Croker (2008) argue that deafness, itself, does not cause cognitive impairments, but the reduced auditory stimulation may lead to differences in the brain functioning. The functioning heterogeneity of deaf or hard of hearing children has been reported consistently through research findings and needs to be considered in intelligence assessment (Wood \& Dockrell, 2010). To investigate heterogeneous functioning in deaf children, Oghalai at al., (2012) assessed the effect of cochlear implants in deaf children with and without developmental delays (DD). Before the implants, children with DD had lower scores on intelligence tests and adaptive behavior. After the implants, a significant increase in intelligence and adaptive behavior was found only in children without $\mathrm{DD}$, indicating that the developmental rate of intelligence in children with DD is lower, but can be improved with implants at earlier ages.

However, there are several difficulties in assessing the intelligence levels of deaf or hearing-impaired children such as a lack of validated instruments for assessing this population, shortcomings in terms of theoretical assumptions, and bias/prejudice and limited knowledge concerning cognitive functioning (Blennerhassett \& Trexler, 1999). The use of inadequate instruments can result in improper assessment of the individuals' real abilities/skills and often leads to the erroneous conclusion that deaf children are cognitively impaired and oftentimes diagnosed with an IQ equivalent to DD children (Krivitski, 2000). Thus, it is necessary to develop psychological tests that are appropriate for deaf children and conduct studies which search for evidence of validity of tests for this population.

The demand for tests that place significantly less emphasis on verbal skills resulted in extensive development of nonverbal tests in the 1990's.
Nonverbal intelligence tests measure skills like perceptual organization, abstract reasoning and problem solving, and they assess intelligence without the need for verbal language on the part of the examiner or the examined. These tests are useful for the assessment of individuals who have cultural, verbal or severe motor impairments that may lead to significant errors in IQ scores when assessed using traditionally administered tests (Bishop, 2005).

According to Mackinson, Leigh, Blennerhasset \& Anthony (1997), the following criteria should be observed in developing nonverbal tests: the type of instruction given by the examiner; the type of answer from the examined subject; and the items' cultural content. The type of instruction given by the examiner may be nonverbal not requiring mastery of a specific language skill. The nature of the examined subject's response may be a motor response, which may be intense or non-intense, with unlimited or limited time to answer. The cultural content of the items refers to the need of the subject to understand information related to his/her culture or academic level.

Braden (1992) conducted a meta-analysis of papers published between 1900 and 1990 and found that the use of signing, gestures and writing improved deaf children's performance. IQ distribution in deaf children was similar to that of hearing children when assessed by nonverbal tests. The results showed that nonverbal tests were also more appropriate than performance scales when, in addition to deafness, the subjects had other health problems or physical conditions that hindered motor activities.

The results obtained on performance scales have been generally accepted as indicators of cognitive abilities of deaf or hard of hearing children. However, Sattler (2001) states that the scale adaptations during application alter the standard testing procedures, thus raising a question about the reliability and validity of the results. Moreover, performance scales that require more intense motor manipulation assess aspects of intelligence that differ from those assessed in nonverbal tests (Braden, 1994). Thus, nonverbal tests are more appropriate for assessing deaf and hard of hearing people, if proper validation, precision and standardization procedures are followed.

Additional changes in test features can be made in order to attend specific needs of deaf people for instance: the use of sign language instead of oral instruction and the allowance of additional time, especially if there are motor limitations (Braden, 2005).

The use of standardized tests for intelligence assessment showed that deaf children born to deaf parents score above the average that is estimated for hearing children in performance tests but the reasons 
for this outcome are still being investigated. The etiology, degree, age at onset and detection of hearing loss, as well as early exposure to language, educational level, parents' auditory status and the presence of other medical conditions are factors that can contribute to differences in cognitive development among these children, which just shows some of the complexities encountered when studying deafness.

Developing countries, such as Brazil, lack appropriate instruments for assessing the academic, cognitive and linguistic development of deaf students. One of the tests that is available is the Test of Nonverbal Intelligence (TONI-3) Form A. The test focuses on abstract problem solving without a demand on verbal skills. It is suitable for subjects from age of 6 to 89 years with reduced linguistic, reading, w riting or motor skills. Thus, it minimizes the need for verbal and motor skills or cultural knowledge and is suitable for populations with special needs such as the deaf, aphasics, people with brain damage, foreigners and others (Brown, Sherbenou \& Johnsen, 1997).

Janse (1980) suggested that tests free of verbal and cultural skills should follow some criteria, such as: low motor skill demand, instruction through pantomime avoiding use of pictures or writing, use of training items, no time limit, abstract content for assessment of problem solving without the need of previous knowledge. These criteria are satisfied by TONI-3.

TONI-3 is comprised of 5 pages of training items and 45 of test. The instructions are administered by pantomime followed by training exercise. According to Brown, Sherbenou and Johnsen (1997) the items are organized according to their complexity and divided into 5 categories that require different problem solving strategies. Although the test was elaborated based on a specific theory about intelligence, the authors state that it is possible to adapt it to different models, such as Spearman's g-factor model, Guilford's Mental Operation system, Cattel-Horn-Carroll model and others.

The TONI-3 offers some advantages, such as training items that enable the subject to get familiar with the test and repeat the trial, should the individual not comprehend the instruction. All test items involve abstract geometric figures and the test has no time limit. The basis of the TONI-3 is abstract reasoning and problem solving. A disadvantage is the lack of normative data for populations with special needs. The norm for TONI-3 was based on individuals with autism spectrum disorders (Kurth \& Mastergeorge, 2010), aphasia patients (Christy \& Friedman, 2005; Yeung \& Law, 2010), Hispanic children without fluency in English (Brown \& cols., 1997), deaf persons (Mackinson, Leigh, Blennerhassett, \& Anthony, 1997), urban children classified as ethnic minorities (Samaha \& Delisi, 2000) and Jamaican students (Barrett, 2000).

In Brazil, the TONI-3 Form A was standardized for the school children population with typical development assessed in Sao Paulo $(n=382)$ and the Form A was already approved by the Federal Board of Psychology (Santos, Noronha \& Sisto, 2006). The data shows that there are good values of internal consistency by Cronbach's Alpha (0.83), Split-Half by Spearman-Brown (0.66) and by Rash's Model (0.79). The correlation between test-retest is very high $(r=0.99 ; \quad p<0.001)$. Some Brazilian studies were conducted with TONI-3 and healthy children (Santos, Sisto \& Noronha, 2010), Down's syndrome (Pacanaro, Santos \& Suehiro, 2009) and Cerebral Palsy (Teixeira, Emerich, Cevallo \& Costa, 2009).

The goal of this study was to assess the intelligence of Brazilian deaf students with the TONI-3 Form $\mathrm{A}$ and to verify differences in factors like gender, age, schooling, the type of deafness, the use of a hearing aid and the subject's means of communication.

\section{Method}

Participants

Two hundred and five deaf students participated in the study, 86 females and 119 males. The age of participants ranged from 6 to 25 years, with a mean age of 14 years old $(S D=4.4)$. The participants were students from the first to ninth grade from one regular state school and two municipal special-education schools in Sao Paulo state, and one special-education school in Pernambuco state. Participants with motor difficulties or with test-comprehension difficulties were excluded from the test, as were deaf students who did not employ any type of communication. Table 1 summarizes the distribution of participants in each grade in the respective schools and the total number of students per school and per grade. 
Table 1. Distribution of students according to the school and school grade

\begin{tabular}{lcccccccccc}
\hline School & 1st & 2nd & 3rd & 4th & 5 th & 6th & 7th & 8th & 9th & Total \\
\hline 1 & - & - & - & - & 1 & 2 & 2 & 1 & 8 & 14 \\
2 & 7 & 16 & 22 & 12 & 10 & 8 & 15 & 6 & 5 & 101 \\
3 & - & - & 1 & 1 & 4 & 1 & 6 & 2 & - & 15 \\
4 & - & 11 & 10 & 9 & 14 & 5 & 16 & 2 & 8 & 75 \\
Total & 7 & 27 & 33 & 22 & 29 & 16 & 39 & 11 & 21 & 205 \\
\hline
\end{tabular}

Legend: 1) State School of regular Education - SP; 2) Municipal School of Special Education - SP; 3) Municipal School of Special Education - SP; 4) Municipal School of Special Education - Recife-Pernambuco.

In regard to hearing loss, out of the 205 students assessed, only 156 had some degree of hearing loss reported in their school records, based on an auditory assessment with hearing loss scale ranging from 1 to 4 . No child was reported as a level 1 (mild); 11 children were classified as level 2 (moderate); 47 were classified as level 3 (severe); and 98 children were considered to be level 4 (profound).

According to the school records, 75 students used hearing aids, 93 did not and the other students were unspecified. Of the 75 students who used hearing aids, 16 had moderate hearing loss, 18 had severe loss and 41 had profound loss.

Signing or verbal means of communication was reported for the total of 183 children, with 84 using only sign language, 3 using only verbal communication and 96 using both sign and verbal communication. Table 2 shows the distribution of students along the different grades as reported in their records regarding hearing loss and mean of communication.

Table 2. Distribution of students according to hearing lost, mean of communication and school grade

\begin{tabular}{lcccccccccc}
\hline & \multicolumn{10}{c}{ School grade } \\
\hline Hearing aid & 1 & 2 & 3 & 4 & 5 & 6 & 7 & 8 & 9 & Total \\
Hearing loss & & 21 & 23 & 5 & 12 & 4 & 7 & 2 & 1 & 75 \\
$\quad$ Moderate & & & & & & & & & & \\
Severe & - & 2 & 1 & - & 3 & 3 & 2 & - & - & 11 \\
$\quad$ Profound & - & 4 & 8 & 8 & 6 & 3 & 10 & 4 & 4 & 47 \\
Uninformed & 1 & 14 & 22 & 10 & 15 & 6 & 17 & 5 & 8 & 98 \\
\hline
\end{tabular}

\section{Instrument}

The Test of Nonverbal Intelligence TONI-3 Form A (Brown, Sherbenou \& Johnsen, 1997) is used to assess a subject's ability to solve abstract problems without depending on the verbal skills of the subject. In the Brazilian version, it can be used with subjects of ages 6 to 10 years and is intended for people with limited language, reading, writing or motor skills. The test minimizes possible linguistic, motor or cultural factors; thus, it is an interesting option for testing populations with special needs, such as deaf people, aphasia patients, patients with brain injuries, foreigners and others (Brown, Sherbenou \& Johnsen, 1997).

The reliability of TONI-3 for deaf students analyzed by Split-Half Spearman-Brown's Coefficient showed satisfactory value $(0.83)$ and a positive and moderate correlation between two forms (0.71). These data indicate adequacy of the internal consistency and homogeneity of TONI-3 for this sample (Urbina, 2004).

\section{Procedures}

Initially, the schools were contacted in order to obtain the project's approval. After the approval, a Letter of Explanation regarding the research was sent to the students' parents or guardians, together with the Informed Consent Form. The participants' parents or guardians were also asked to fill out an Application Form with personal data, information regarding the type of deafness, its onset and socioeconomic data regarding each subject. An explanation was given to those students whose parents or guardians had agreed to the students' participation in the research project, and only those students who voluntarily agreed were assessed.

Tests were administered in the schools at a time previously agreed upon with the professor so as not to penalize the student for leaving the classroom; the duration of the administered test was an average of 15 minutes. Assessment was carried out by the paper`s first author and a teacher, using sign language.

Psico-USF, Bragança Paulista, v. 18, n. 2, p. 183-192, maio/ agosto 2013 
Variance analyses were conducted to compare the performance between groups according to age, grade, gender, hearing loss and means of communication. The statistics software SPSS version 15.0 was used and the level of significance adopted for all the analyses was $5 \%$.

\section{Results}

A univariate analysis of variance was conducted to determine a gender difference, with the age as a covariant. Gender difference did not prove to be statistically significant $(F[2,1]=1.804 ; p=0.181)$. The data were pulled together and single-factor analysis of variance was conducted in order to verify if the test discriminated subjects based on age.

Subjects were grouped into two-year age intervals, in order to increase the number of participants in each age group. A similar grouping was done in the TONI 3 validity study in Brazilian children (Santos, Noronha \& Sisto, 2006). Thus, subjects of ages 6 and 7 years comprised one group, 8 and 9 years another group and so on. Table 3 shows average scores on the TONI- 3 as a function of age.

Table 3. Average scores on the TONI-3 according to age group

\begin{tabular}{cccc}
\hline Age & $\mathrm{N}$ & Total (mean score) & SD \\
\hline $6-7$ & 11 & 12.36 & 3.77 \\
$8-9$ & 22 & 15.18 & 3.99 \\
$10-11$ & 31 & 15.93 & 5.37 \\
$12-13$ & 37 & 17.62 & 5.75 \\
$14-15$ & 32 & 23.03 & 6.30 \\
$16-17$ & 24 & 20.83 & 5.68 \\
$18-19$ & 20 & 22.15 & 6.15 \\
$20-21$ & 13 & 18.38 & 5.15 \\
$22-13$ & 10 & 21.4 & 5.83 \\
$24-25$ & 5 & 15.4 & 1.14 \\
\hline
\end{tabular}

The analysis showed a significant increase in scores with an age $(F[9,195]=5.445, p<0.001)$. A posthoc analysis (LSD) showed an increase in the scores throughout the different age groups. A statistically significant difference was observed between the groups of children of 6 and 7 years, 12 and 13 years and upwards. The group with ages of 8 to 11 years showed a statistically significant difference compared to that of 14 and 15 years and upwards. Finally, the group aged 12 and 13 years showed a statistically significant difference compared to the groups aged 16 and upwards. However, no significant differences were observed between the ages of 20 and 21 years compared to other groups, except for children of 6 and 7 years.

Linear increase was found from the $1^{\text {st }}$ through the $8^{\text {th }}$ grades, with participants from the $1^{\text {st }}$ grade scoring lower than those in the $2^{\text {nd }}$ grade, and so on. This linear pattern failed to hold up, only in the 9 th grade, since these students scored worse than students in the $8^{\text {th }}$ grade. Table 4 shows average correct responses to the TONI-3 throughout the grades.

Table 4. Average scores on the TONI-3 along the grades

\begin{tabular}{lcccccccccc}
\hline & 1 grade & 2 grade & 3 grade & 4 grade & 5 grade & 6 grade & 7 grade & 8 grade & 9 grade & Total \\
\hline $\mathrm{M}$ & 11.00 & 14.63 & 15.78 & 17.22 & 18.17 & 19 & 20.66 & 24.90 & 21.28 & 18.19 \\
$\mathrm{SD}$ & 4.24 & 4.03 & 4.94 & 5.07 & 6.30 & 4.71 & 5.30 & 6.33 & 5.94 & 5.99 \\
\hline
\end{tabular}

In order to verify the effect of the grades on participants' scores a univariate analysis of variance was conducted. An analysis of the scores showed a significant increase along the grades $(F[8,196]=8.330$; $p<0.001$ ). A post-hoc analysis (LSD) was conducted to identify differences between the grades. There were no statistically significant differences in $1^{\text {st }}$ grade to the $3^{\text {rd }}$ grade and upwards, the $2^{\text {nd }}$ grade to $5^{\text {th }}$ grade and above, the $3^{\text {rd }}$ grade to $6^{\text {th }}$ and above, the $4^{\text {th }}$ to the $7^{\text {th }}$ and upwards, the $5^{\text {th }}$ and $6^{\text {th }}$ to $8^{\text {th }}$, and no differences were observed in the $9^{\text {th }}$ grade to the $6^{\text {th }}, 7^{\text {th }}$ and $8^{\text {th }}$.

In order to assess the effect of a hearing aid on TONI-3 performance, an ANCOVA with age and grade as covariance was conducted. The results showed that subjects with hearing aids $(M=18.756 ; S D=8.881)$ scored higher than those $(F[1,173]=4.555 ; p<0.035)$ without hearing aids $(M=17.19 ; S D=5.46)$. 
Regarding the mode of communication, ANCOVA was conducted controlling the effect of age and grade. Due to the limited number of participants in the exclusively verbal communication mode $(n=3)$, the analysis only considered the communication conditions as a combination of verbal language and signs or proprietary signs. The results showed no statistically significant difference between groups $(F[1.173]=0.073$, $p=0.787$ ).

In order to verify whether there was a difference in the test score regarding the type of hearing loss (moderate, severe and profound), ANCOVA was conducted, with the school grade and age as co- variants. No significant scoring difference was found $(F[1.141]=2.917 ; p=0.090)$ for moderate $(M=16.90$; $S D=4.27)$, severe $(M=19.51 ; S D=6.38)$ and profound hearing loss $(M=17.44 ; S D=5.19)$.

The age groups' mean scores were compared with the scores of hearing children available in the manual of TONI-3 for Brazilian population of 6 to 11 years old (Santos \& cols., 2006). There were no significant differences between groups of the ages of 6 to 7 years. However there were significant differences for age groups of 8 to 9 and 10 to 11 years old. Descriptive and inferential statistics are presented in Table 5.

Table 5. Mean score on TONI-3 of normally hearing children and deaf children

\begin{tabular}{lccccccc}
\hline & \multicolumn{2}{c}{ Hearing children } & \multicolumn{2}{c}{ Deaf children } & & \\
Age groups & $M$ & $S D$ & $M$ & $S D$ & $t$ & $d f$ & $p$ \\
\hline $6-7$ & 13.95 & 5.91 & 12.36 & 3.77 & -0.87 & 141 & 0.383 \\
$8-9$ & 17.20 & 5.83 & 15.18 & 3.99 & -2.06 & 36 & 0.046 \\
$10-11$ & 19.07 & 6.33 & 15.93 & 5.37 & -2.50 & 132 & 0.013 \\
\hline
\end{tabular}

The results showed a better outcome with hearing children compared to the deaf or hard of hearing children. The difference in the outcome was greater for higher age groups but since the available data for hearing children ranged up to 11 years only, it was not possible to confirm a continuous tendency.

\section{Discussion}

This article presented data resulting from the intelligence assessment of Brazilian deaf or hard of hearing children using the Test of Nonverbal Intelligence TONI-3 Form A. Analyses were carried out regarding the relationships between the participants' scores and variables such as gender, age and education. The results showed no significant difference with respect to gender indicating there was similar performance between men and women on the test. The absence of a gender effect confirmed the findings of Santos et al. (2006), who used the TONI-3 to assess 382 Brazilian hearing children, 191 male and 191 female, and found no gender difference in scoring. These findings support previous results in the literature that showed no gender differences in general intelligence when nonverbal tests were used (Flynn \& Rossi-Casé, 2011).

This study also showed the effect of age and schooling on the score obtained on the TONI-3 test, with higher scores observed with increasing age and education level. In assessing Brazilian hearing children using the same test, Santos et al. (2006) found a similar pattern, which may be interpreted as a source of evidence validity associated with age (APA, AERA \&
NCME, 1999). According to Urbina (2004) test results that are consonant with well established developmental trends across age groups are often seen as being evidence of score validity in most ability tests such as TONI-3. Thus, the results obtained with Brazilian deaf and hard of hearing students using the TONI-3 was evidence of the instrument's validity.

However, regarding the increase of scores according to progression of age, it was observed that unlike the normative data (Santos et al. 2006), statistically significant differences were found among age groups in this study. The results of the analyses indicated that children belonging to the age group of 6 7 years underperformed in relation to children from group of 12 years. The same was observed in the group of 8-9 years whose performance was lower only when compared to students from the group of age 14 . Although for the age groups from 10 years upthis gap has decreased, it was higher than expected in Brazilian normative sample.

Although there was an increasing function in the score in relation to age and education, in some cases, the mean score of younger students was higher than that of their elders. Such discrepancies can be explained as a function of sample size for each series. Regarding the selection of the sample in this study, older students were still atending elementar school. A number of factors contribute to this situation, such as little or no early language stimulation, late detection of hearing loss, other causes that lead to a delay in school enrollment or a need for more time to finish a middle school education and late access to schooling. Therefore, it is also important to highlight the Psico-USF, Bragança Paulista, v. 18, n. 2, p. 183-192, maio/ agosto 2013 
influence of schooling on the test's scores since an increase in cognitive skills, such as IQ, may be related to a greater number of years in school (Barber, 2005).

In a study with large samples and assessment of cognitive abilities that are more influenced by academic performance, this linear function has been well established as noted by Giacomet (2007) who evaluated more than 5000 deaf people at proof reading and writing and noted an increasing linear function throughout the series and ages.

The analyses carried out regarding the type of hearing loss and of communication used by the subjects did not correlate to significant test scoring differences. According to Vernon's revision of papers reporting studies on intelligence in deaf people in the last 50 years, there is no relation between intelligence level and factors such as severity of hearing impairment, language or cultural deprivation. To the contrary, a higher prevalence of low IQ in deaf or hard of hearing students can be due to the different etiologies of deafness, which besides hearing impairment, may also lead to mental retardation (Vernon, 2005).

The scores of Brazilian hearing children in the study of Santos et al. (2006) were higher than those observed in this study with deaf and hard of hearing children. This difference showed a growing tendency in higher age groups. The tendency may be due to a nonlinear function between age and grade, which means that in Brazil, older deaf students frequently study in grades that are lower than would be appropriate for their age. In order to better verify the impact of early and continuous education on the intelligence test's score, it is important to further assess deaf and hard of hearing students in high school and universities.

\section{Conclusions}

The aim of this study was to look for evidence of validity of the TONI-3 for Brazilian deaf and hard of hearing people. The findings reveal that the test may be useful in assessing these individuals. However, in future studies, it may be interesting to include Brazilian deaf students enrolled in high school and universities, in order to better understand the impact of continuous education on the test s outcome. It is also necessary to assess the performance of children and youth from different cultural environments in Brazil.

\section{References}

American Educational Research Association [AERA], American Psychological Association [APA] \& National Council on Measurement in Education
[NCME] (1999). Standards for educational and psychological testing. New York: American Educational Research Association.

Barber, N. (2005). Educational and ecological correlates of IQ: a cross-national investigation. Intelligence, 33, 273-284.

Barrett, P. (2000). Validation of Test of Nonverbal Intelligence.Third Edition for Jamaican Studants. Dissertation Abstracts International, 6(11-B), 582.

Bishop, D. (2005). Nonverbal Tests of Intelligence.Technical Assistence Paper. Florida: Bureau ofexceptional education and students services, FY, 8, 1-12.

Blennerhassett, L. \& Traxler, C. B. (1999). WISC - III Utilization with deaf and hard of hearing students. Gallaudet Research Institute Technical Report. Washington DC: Gallaudet University Press.

Braden, J. P. (1992). Intellectual assessment of deaf and hard-of-hearing people: a qualitative and quantitative research synthesis. School Psychology Review, 21, 82-94.

Braden, J. P. (1994). Deafness, deprivation, and IQ. New York, NY: Plenum Press.

Braden, J. P. (2005). Hard of hearing and deaf clients: Using the WISC-IV with clients who are hard of hearing or deaf. In A. Priftera, D. H. Saklofske \& L. G. Weiss (Eds.), WISC-IV: Clinical use and interpretation. Scientist-practitioner perspectives. London: Elsevier Academic Press.

Brown, L., Sherbenou, R. J. \& Johnsen, S. K. (1997).Test of Nonverbal Intelligence .Third Edition - A Language-free Measure of Cognitive Ability.Austin, Texas: Pro-ed.

Christy, E. M. \& Friedman, R. B. (2005). Using nonverbal tests to measure cognitive abillity inpatients with aphasia: A comparison of the RCPM and the TONI. Brain and Language, 95, 195196.

Edward, L. \& Crocker, S. (2008). Psychological processes in deaf children with complex needs: An evidence-based practical guide. London: Jessica Kingsley.

Flynn, J. R. \& Rossi-Casé, L. (2011). Modern women match men on Raven's Progressive Matrices. Personalityand Individual Differences, 50, 799-803.

Giacomet, A. (2007). Análise de paragrafias do surdo na nomeação de sinais por escrita livre: teste de nomeação de sinais por escrita de palavras, versões 1.2 e $2.2 \mathrm{com} 5.086$ estudantes surdos de $1^{a}$ a $13^{a}$ série de 14 estados brasileiros. 2007. Dissertação de Mestrado. (Programa de Pós-Graduação em Psicologia) Universidade de São Paulo, São Paulo.

Huber, M. \& Kipman, E. (2012). Cognitive Skills and Academic Achievement of Deaf Children with 
Cochlear Implant. Otolaryngol Head Neck Surg, 147(4):763-772.

Krivitski, E. C. (2000). Profile Analysis of Deaf Children Using the UNIT. Dissertation Abstracts International, 61(7-A), 2593.

Krouse, H. E. \& Braden, J. P. (2011).The Reliability and Validity of WISC-IV Scores With Deaf and Hard-of-Hearing Children. Journal of Psychoeducational, 29(3): 238-248.

Kurth, J. A. (2010). Academic and Cognitive Profiles of Students with Autism: Implications for Classroom Practice and Placement. International Journal of Special Education, 25(2): 8-14.

Kushalnagar, P., Krull, K., Hannay, J., Mehta, P., Caudle, S. \& Oghalai, J (2007). Intelligence, Parental Depression, and Behavior Adaptability in Deaf Children Being Considered for Cochlear Implantation. Journal of Deaf Studies and Deaf Educatio, 12(3): 335-349.

Mackinson, J. A., Leigh, I. W., Blennerhasset, L. \& Anthony, S. (1997).Validity of the TONI-2 with deaf and hard of hearing children. American Annals of the Deaf, 42, 294-9.

Nisbett, R. E., Aronson, J., Blair, C., Dickens, W., Flynn, J., Halpern, D. F. \& Turkheimer, E. (2012). Intelligence: New findings and theoretical developments. American Psychologist, 67(2): 130-159.

Oghalai, J. S.,Caudle, S. E., Bentley, B., Abaya, H., Lin, J., Baker, D., Emery, C., Bortfeld, H. \& Winzelberg, J. (2012). Cognitive outcomes and familial stress after cochlear implantation in deaf children with and without developmental delays. (2012). Otol Neurotol, 33(6): 947-56.

Pacanaro, S. V., Santos, A. A. A. \& Suehiro, A. C. B. (2009). The validity of the TONI-3 for assessing people with Down Syndrome. Arq. Bras. Psicol, 61 (3): 107-116.
Samaha, N. \& Delisi, R. (2000). Peer collaboration on a nonverbal reasoning task by urban, minority students. Journal of Experimental Education, 69(1), 5223.

Santos, A. A. A., Noronha, A. P. P. \& Sisto, F. F. (2006). TONI-3: Estudos Psicométricos no Brasil. São Paulo, SP: Vetor Editora Psicopedagógica.

Santos, A. A. A., Sisto, F. F. \& Noronha, A. P. (2010). TONI-3 Form A and Cloze Test: Evidence of Validity. Psicologia: Teoria e Pesquisa, 26(3): 399-405.

Sattler, J. M. (2001). Assessment of Children (4th edition). San Diego: Jerome M Sattler, Publisher, Inc.

Teixeira, M. C. T. V., Emerich, D. R., Cevallos, P. V. \& Costa, M. L. (2009). Functional independence measure in adults with cerebral palsy: relation with cognitive abilities and behavioral profile. Acta Fisiatr, 16(4): 162-167.

Urbina, S. (2004). Essentials of Psychological Testing: Essentials of Behavioral Science Series. Hoboken, NJ: John Wiley \& Sons Inc.

Vernon, M. (2005). Fifty Years of Research on the Intelligence of Deaf and Hard-of-hearing Children: A Review of Literature and Discussion of Implications. The J. Deaf Stud.Deaf Educ, 10, 225-231.

Wood, N. \& Dockrell, J. (2010). Psychological assessment procedures for assessing deaf or hardof-hearing children.Educational \& Child Psychology, 27(2): 11-22.

Yeung, O. \& Law, S. (2010). Executive functions and aphasia treatment outcomes: data from an orthophonological cueing therapy for anomia in Chinese. Int J Speech Lang Pathol, 12(6): 529-44.

Recebido em 28/08/2012

Reformulado em 31/01/2013

Aprovado em 26/03/2013 
Nota dos autores:

Agradecimentos e apoio financeiro - Editora Vetor e Instituto Presbiteriano Mackenzie-Mack Pesqusia

Sobre os autores:

Anna Carolina Cassiano Barbosa é psicóloga, mestre e doutora em Distúrbios do Desenvolvimento pela Universidade Presbiteriana Mackenzie. Professora do curso de Psicologia da Universidade Cruzeiro do Sul e da Pósgraduação em Psicopedagogia da Universidade Presbiteriana Mackenzie. Atua principalmente nos seguintes temas: avaliação neuropsicológica, testes computadorizados, dislexia, distúrbios de aprendizagem, psicopedagogia e programas de intervenção.

Katerina Lukasova é psicóloga e mestre em Distúrbios do Desenvolvimento pela Universidade Presbiteriana Mackenzie. Doutora em Ciências pela Faculdade de Medicina da Universidade de São Paulo. Professora da Universidade Cruzeiro do Sul. Atua principalmente nos seguintes temas: avaliação neuropsicológica, distúrbios de aprendizagem, desenvolvimento de testes neuropsicológicos e programas de intervenção.

Tatiana Pontrelli Mecca é psicóloga, mestre e doutoranda em Distúrbios do Desenvolvimento pela Universidade Presbiteriana Mackenzie. Bolsista FAPESP. Professora convidada da pós-graduação em Psicopedagogia da Universidade Presbiteriana Mackenzie. Atua na área de avaliação neuropsicológica de crianças e adolescentes com Transtornos Globais do Desenvolvimento e realização de estudos psicométricos de instrumentos não verbais para avaliação cognitiva.

Elizeu Coutinho Macedo é psicólogo, mestre e doutor em Psicologia Experimental pela Universidade de São Paulo pela Universidade de São Paulo. Atualmente é professor adjunto da Universidade Presbiteriana Mackenzie e atua na área de avaliação neuropsicológica nos Transtornos de Aprendizagem e desenvolvimento de instrumentos computadorizados para avaliação e reabilitação neuropsicológica, comunicação alternativa e suplementar.

\section{Contato com os autores:}

Programa de Pós-Graduação em Distúrbios do Desenvolvimento - Laboratório de Neurociência Cognitiva e Social Rua Piauí, 181 - 10ª andar - Consolação - CEP 01302-000 - São Paulo-SP, Brasil

E-mail: carol.cassiano@gmail.com 